\title{
Hemophagocytic Lymphohistiocytosis: A Review
}

Sirisha Rani Siddaiahgari ${ }^{*}$, Shirali Agarwal, Pallavi Madukuri and Latha Subramanyam Moodahadu

Rainbow Children's Hospital, Hyderabad, India

"Corresponding author: Sirisha Rani Siddaiahgari, Department of Hemato oncology, Rainbow Children's Hospital, 22, Road No. 4, (Old Road No. 10), Karvy Lanes, Banjara Hills, Hyderabad, Telangana, India, Tel: 09959985558; E-mail: lokisiri@gmail.com

Received date: Jun 15, 2016, Accepted date: Jul 30, 2016, Publication date: Aug 03, 2016

Copyright: (c) 2016 Siddaiahgari SR, et al. This is an open-access article distributed under the terms of the Creative Commons Attribution License, which permits unrestricted use, distribution, and reproduction in any medium, provided the original author and source are credited.

\begin{abstract}
Hemophagocytic lymphohistiocytosis (HLH) is a disorder charecterised by immune dysregulation. Though it was underdiagnosed earlier now it is increasingly being diagnosed across the world with better awareness among physicians. "Hypercytokinemia" which is the hallmark of HLH can result in end organ damage and even death in some cases if there is delay in diagnosis. It has a wide array of presentation but commonly presents as fever with organomegaly and bicytopenia. A vast majority of cases are acquired due to secondary causes but primary HLH is also not uncommon which also intern gets triggered by infection as suggested by recent studies. Laboratory parameters like Ferritin, triglycerides and fibrinogen along with bicytopenia/pancytopernia aid in further confirmation of this diagnosis. Bone marrow may or may not show evidence of $\mathrm{HLH}$, Hence absence of involvement should not exclude the diagnosis of $\mathrm{HLH}$. Newer modalities like flow cytometry and genetic analysis have contirbuted for widespread recognition of its pathogenesis and etiology. Like various other emergencies, timely diagnosis remains one of the key stones of its management. Management is largely based on HLH-2004 protocol for secondary cases and almost all cases of primary HLH require Hematopeitic Stem Cell transplantation after initial treatment with HLH 2004 protocol. Recent advances have been made in exploring other modalities of treatment like immunomodulatory agents and monoclonal antibodies (ATG, Alemtuzumab, IFN-y) for resistant/refractory cases to achieve desirable outcomes. Our article aims to summarize the new advances in the diagnosis and management of $\mathrm{HLH}$ and also gives comprehensive review of the pathophysiology, clinical observations and modern laboratory methods for HLH diagnosis. Early and prompt recognition remains the gold standard to decrease the mortality related to this condition.
\end{abstract}

Keywords: Hemophagocytic lymphohistiocytosis diagnostic criteria and management; Flow cytometry role in diagnosis; Newer modalities of HLH treatment

\section{Introduction}

Hemophagocytic Lymphohistiocytosis (HLH), a rare phenomenon of immune dysregulation, primarily recognized in pediatric patients, is relatively under diagnosed owing to varied manifestations and lack of awareness among medical fraternity. It can either be sporadic or familial, generally being precipitated by a triggering event such as infection or malignancy. It was first reported in 1952 by Farquhar and Claireaux. Chemotherapy has proved very effective in controlling and curing HLH apart from prolonging survival.

It affects both genders though slight male predisposition is seen in adolescents [1,2]. Incidence is reported to be as high as1 in 3000 in pediatric hospital admissions. Positive family history such as parental consanguinity and death of a sibling can be a leading clue owing to autosomal recessive nature of inheritance $[3,4]$.

Early diagnosis of this rare but fatal condition is crucial as the spectrum of clinical presentation varies from simple fever to severe inflammation "i.e.," organomegaly, bicytopenias and occasionally end organ damage, mimicking frequently encountered pathological entities. This increases the chances of misdiagnosing the condition, but associated cutaneous changes in HLH prompt the physician to suspect.

HLH is of clinical interest to us because of its ability to mimic any symptom. In developed countries where they have lesser number of infections, diagnosis can be made without much difficulty, whereas in developing countries like India, where infections are still a major concern to the physicians, making an accurate diagnosis, is crucial.

In this review we discuss various aspects of HLH which includes classification, pathophysiology, clinical features, investigations, standard treatment, proposed treatment modalities, and future scope. Through this review we intend to create and increase the awareness among medical fraternity particularly pediatricians.

\section{Classification}

HLH is classified based on its aetiology [5] (Figure 1). Distinguishing primary from secondary is crucial as management is different in each type. Primary HLH is seen in pediatric age group while secondary is common among adults and elderly. The genetic forms of HLH can be divided into Familial HLH (FHLH) associated with immunodeficiency syndromes and without any association with syndromes. Family history may not be elicitable owing to recessive nature of the disease. Most of the genes implicated are the ones coding components of perforin gene accounting for $50 \%$ of all FHL cases $[6,7]$. There exist other genetic defects in regulating the packaging, transport, or release of cytotoxic granules. Table 1 shows characteristics of mutations observed at FLH loci $[1,8,9]$ and its genetic defect.

The immunodeficiency syndromes to be associated with HLH (Table 2) are Chédiak-Higashi syndrome (CHS-1), Griscelli syndrome type 2(GS-2) [10,11], Hermansky-Pudlak syndrome type 2, and Xlinked proliferative syndrome (XLP-1) also called Duncan disease, characterized by an abnormal response to Epstein Barr virus infection (Table 2). 
Most common form is secondary HLH and many of these cases occur following infections. Clinically HLH can also be seen in association with rheumatological conditions such as Juvenile Idiopathic arthritis or systemic lupus erythematosus (SLE). New terminology 'Macrophage Activation Syndrome' (MAS) has been proposed for this type of HLH. Rheumatologic disorders causing MAS are systemic onset juvenile idiopathic arthritis, SLE, polyarteritisnodosa, mixed connective tissue disease, sarcoidosis, systemic Sclerosis, and Sjögren's syndrome and Antiphospholipid syndrome.

Emergence of newer informations, updates and findings have necessitated the need of revisions in the classification of HLH. Working group of the Histiocyte Society has considered only three types of cells i.e., Langerhans cells, non-Langerhans related, and malignant histiocytosis in their classification. Emile et al. [12] have suggested a revision to the existing classification by including two more cell types. They have suggested Langerhans-related, cutaneous and mucocutaneous, malignant histiocytoses Rosai-Dorfman disease hemophagocytic lymphohistiocytosis and macrophage activation syndrome in the proposed classification.

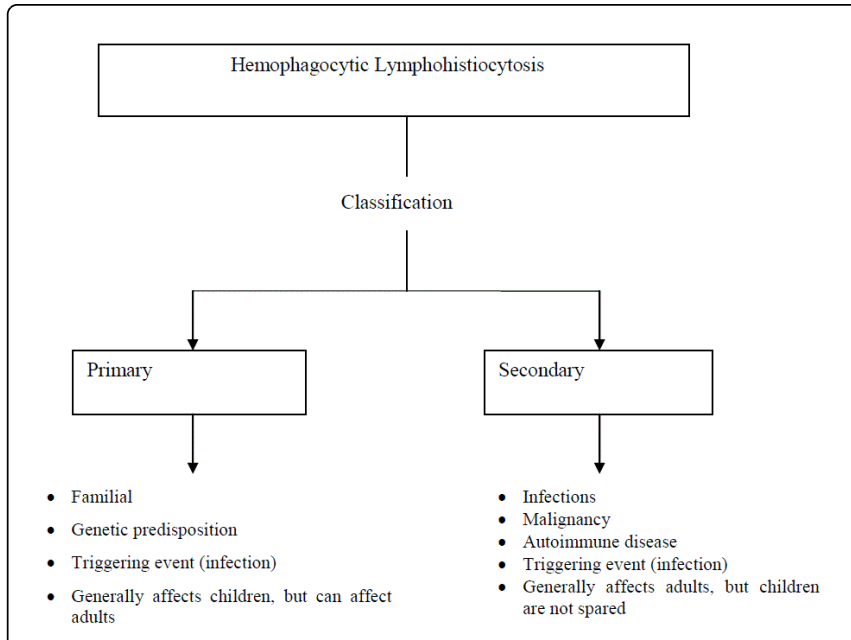

Figure 1: Classification of HLH based on aetiology.

\begin{tabular}{|l|l|l|l|l|}
\hline FHL subclass & Chromosome & Gene & Gene function & Protein \\
\hline FHL-1 & $9 \mathrm{q} 21.3-\mathrm{q} 22$ & Unknown & Unknown & Unknown \\
\hline FHL-2 & $10 \mathrm{q} 21-22$ & PFR1 & Induction of apoptosis & Perforin \\
\hline FHL-3 & $17 q 25$ & UNC13D & Vesicle priming & Munc13-4 \\
\hline FHL-4 & $6 q 24$ & STX11 & Vesicle transport & Syntaxin11 \\
\hline FHL-5 & $19 p 13.2-3$ & STXBP2 (UNC18B) & Vesicle transport & Munc18-2 \\
\hline
\end{tabular}

Table 1: Mutations at FLH loci and its genetic defect.

\begin{tabular}{|c|c|c|c|c|}
\hline Syndrome & Chromosome & Gene & Gene function & Protein \\
\hline CHS-1 & $1 q 42.1-q 42.2$ & LYST & Vesicle transport & Lyst \\
\hline GS-2 & $15 q 21$ & RAB27A & Vesicle transport & Rab27a \\
\hline XLP-1 & Xq25 & SH2D1A & Signal transduction and activation of lymphocytes & SAP \\
\hline XLP-2 & Xq25 & BIRC4 & Various signaling pathways & XIAP \\
\hline
\end{tabular}

Table 2: Mutations associated with various Syndromes with HLH.

\section{Pathophysiology}

HLH is a syndrome of extensive inflammation due to abnormal activation of immune cells, which results in lack of normal down regulation of activated macrophages and lymphocytes which then cause tissue destruction [13]. In HLH the impaired cytotoxic function of natural killer (NK) cells and cytotoxic lymphocytes (CTLs) results in faulty elimination of macrophages, leading to uncontrolled activation [14-20]. Lysis of target cells is a cascade, where in there is formation of a immunological synapse creating a pore in macrophages following which there is an exchange of cytolytic granules containing granzyme and other proteins which eventually causing apoptosis of the cells (Figure 2).

The genetic defects occurring at various levels of this cascade in $\mathrm{HLH}$, hinders the normal apoptosis causing excessive activation of macrophages and hypercytokinemia (Figure 2) [12]. These cytokines are interferon gamma, tumor necrosis factor alpha (TNF- $\alpha$ ), interleukins (IL) such as IL-6, IL-10, and IL-12; and the soluble IL-2 receptor (CD25). Elevated IL-16 is important for TH1-type response that recruits macrophages and other cells causing HLH [21-23]. Another cause of HLH is activation of Toll-like receptor (TLR) [24] which are non-antigen-specific receptors on the surface of NK cells that can be activated by components of bacteria, fungi, viruses, or mycoplasma (Figure 2). In MAS, genes causing TLR/interleukin 1 receptor (IL-1R) signalling are upregulated [25] resulting in hemophagocytosis.

The precipitating factor is infection in most cases triggering an acute episode and leading to immune homeostasis alteration. The most commonly implicated organisms are viruses "i.e.," Epstein-Barr virus, cytomegalovirus, parvovirus, herpes simplex virus, varicella-zoster 
virus, HIV etc.), bacteria (Brucella, gram negative bacteria, tuberculosis), parasites (Leishmaniasis, Malaria) and fungi [26,27]. Positive association between HLH and malignancies like leukemias, lymphomas and solid tumors have been well documented [28]. Genetic understanding is essential for the physician to determine likelihood of recurrence, the need for hematopoietic cell transplant, and the risk of HLH in family members.

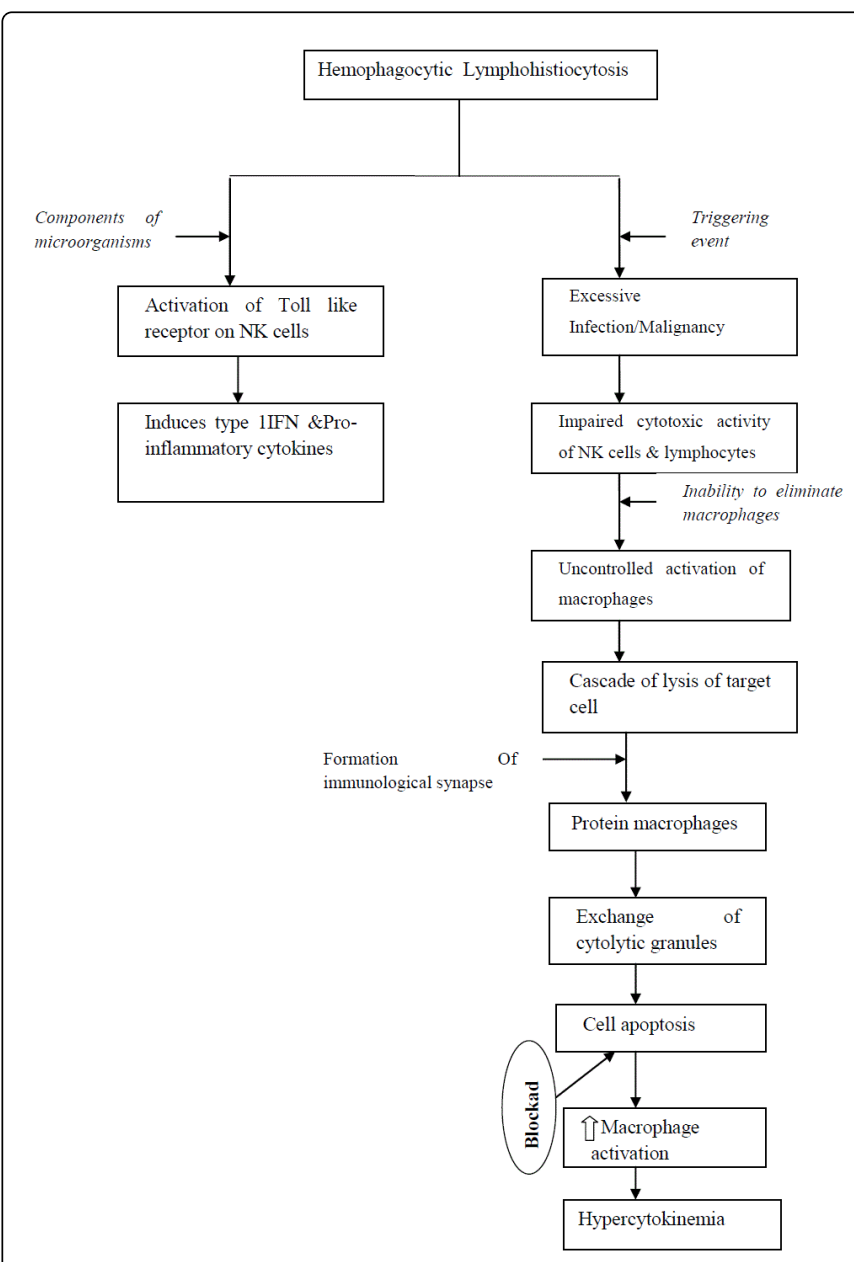

Figure 2: Pathophysiology of HLH.

\section{Clinical Features}

Clinical features of HLH have wide spectrum, thus arriving at accurate diagnosis is challenging. The presenting features is generally a febrile illness associated with multiple organs involvement "i.e.," fever, rash (erythroderma), hepatosplenomegaly, lymphadenopathy, edema, bleeding manifestations, icterus, liver dysfunction and neurological symptoms such as seizures, altered mentation, ataxia and posterior reversible encephalopathy syndrome (PRES) like picture especially in case of FHLH.

Magnetic resonance imaging (MRI) of the brain in these patients can show hypodense to necrotic areas. Almost around half of FHLH patients have CNS involvement [29]. If central nervous system (CNS) involvement is present there is a manifold increase in the risk for mortality and neurologic sequelae $[4,30,31]$.
Presenting with features of respiratory problems like ARDS, hypotension and renal dysfunction even requiring dialysis, syndrome specific features like albinism, photosensitivity and silvery grey hair like in chediak higashi/griscelli syndrome are not uncommon.

Despite well recognized characteristic symptoms, diagnosis is difficult as the clinical presentation may mimic many other clinical conditions [30]. Investigations aid in arriving at a diagnosis of HLH; hence, it is essential to follow a thorough work up.

\section{Investigations}

\section{Laboratory Investigations and findings observed in HLH}

\section{Complete blood picture}

Complete blood picture $(\mathrm{CBP})$ is done routinely on all patients as they present with feature of infection and with an h/o infection as triggering event. It is evident that $>80 \%$ of patients develop bicytopenia/pancytopenia [30,32]. Clinical symptoms with cytopenia should lead the pediatrician to suspect HLH.

Delayed onset cytopenia's is the distinguishing factor in MAS as generally these patients have elevated counts prior to the development of HLH.

\section{Liver function and coagulation factors}

Abnormal liver function and coagulation defects are seen in HLH $[30,31]$. Hepatitis is frequently encountered in patients with HLH, manifesting as elevated bilirubin, liver enzymes lactate dehydrogenase (LDH), aspartate amino transferase (AST), alanine aminotransferase (ALT), gamma glutamyl transferase (GGT) and low albumin. Hepatic failiure seen in these patients can vary in severity from mild to fulminant.

Hence, in all patients with HLH Prothrombin time, activated partial thrmoboplastin time (aPTT), fibrinogen, D-Dimer must be investigated.

\section{Markers}

Important biochemistry markers in HLH include ferritin and triglyceride. Highly elevated ferritin is the diagnostic feature of HLH. Hypertriglyceridemia develops secondary to liver involvement. Decreased fibrinogen levels are additional indicators of HLH [33]. Elevated serum neopterin levels were observed in patients with HLH by Ibarra et al. [34] they found this marker as a specific and sensitive marker for the diagnosis of HLH.

\section{Bone marrow examination}

Incidence of bone marrow involvement by hemophagocytosis in $\mathrm{HLH}$ ranges from $25-100 \%$. At times initial stage of disease, no marrow involvement may be seen but may be seen later in the course of disease. However, bone marrow examination is mandatory in these patients to detect hemophagocytosis, to rule out lymphoid malignancy, aplasia and isolation of organisms if cultures are done. Varied cellular pattern of high, low, or normal cells can be noted in HLH. Characteristic diagnostic feature is infiltration of the bone marrow by activated macrophages showing engulfing blood components (Figure 3 ). It is simpler to highlight macrophages by staining for hemoglobinhaptoglobin scavenger receptor CD163 [35]. 


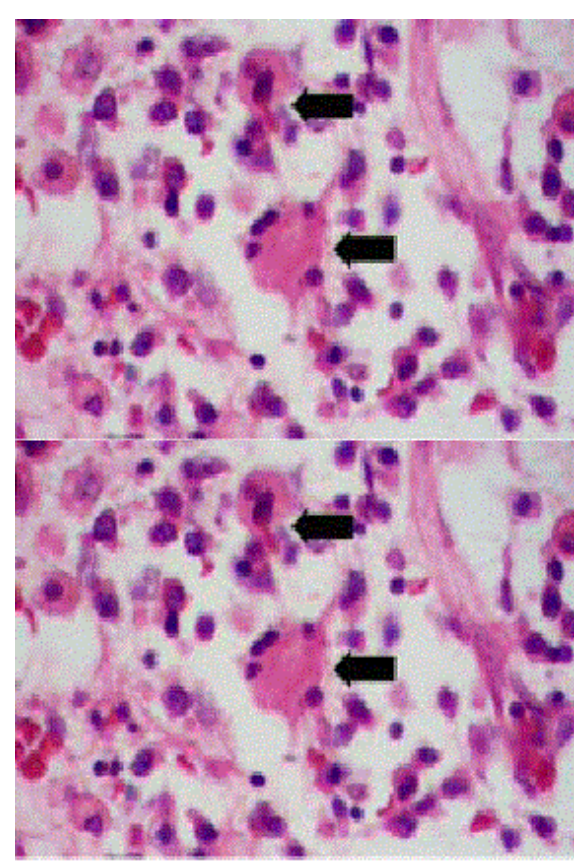

Figure 3: Bone marrow showing hemophagocytosis.

\section{Liver biopsy}

Lymphocytic infiltrates is seen frequently and chronic persistent hepatitis with periportal lymphocytic infiltration can be seen in severe cases.

\section{Cerebrospinal fluid (CSF) analysis}

Cellular pleocytosis, elevated proteins and hemophagocytosis can be detected on CSF analysis. As a part of specialized testing several investigations specially to elicit genetic causes must be performed $[30,31]$.

\section{Immunologic profile}

Underlying disease pathology causes hypercytokinemia. Thus, identifying these cytokines, along with NK cells CTls in immunologic profile has been proved useful in diagnosis [30].

Elevated Soluble IL-2 receptor alpha (sCD25) found to correlate with disease activity [36]. NKcell function/degranulation (e.g. by flow cytometry for surface expression of the lysosomal-associated membraneprotein1 [LAMP-1, also called CD107alpha]) are found to be decreased in these patients.

Low CD107a on peripheral blood mononuclear cells is a marker for UNC13D, STX11, STXBP2, and RAB27Amutatios which can be detected through phyto hemagglutination or antiCD3 stimulation by flowcytometry.

Detection of perforin expression on cytotoxic $\mathrm{T}$ cells by flow cytometry is one of the rapid diagnostic tool to detect homozygous mutations, but with limitations of variable protein expression (especially in heterozygous cases).

Flow cytometry for cell surface expression of SAP and XIAP/ SH2D1A (decreased) can be used in males. Increased levels of the hemoglobin-haptoglobin scavenger receptor (sCD163), Immunoglobulin levels (e.g. IgG, IgA, IgM) and lymphocyte subsets are also useful investigation in the diagnosis of HLH [13,27,37-39].

\section{Genetics and HLA testing}

A genetic analysis is not practical in all cases in developing countries such as India. However, it is mandatory in children with CNS involvement, relapsing/refractory disease, disease with significant multiorgan involvement and children born to consanguineous parents/ with positive family history. Viral titres, body fluids cultures should be performed.

List of parameters to be tested are provided in Tables 1 and 2.

\section{Clinical Investigations}

- Echocardiogram and Chest $\mathrm{X}$ ray should be done wherever relevant to rule out cardiovascular and respiratory aetiology and involvement.

- Imaging of the CNS may show parameningeal infiltrations, subdural effusion and necrosis.

Progressively increasing transaminases, bilirubin, coagulopathy, ferritin, and sCD25 levels as well as deteriorating respiratory status are considered poor prognostic signs.

\section{HLH 2004 Diagnostic Criteria}

Currently, HLH 2004 diagnostic criteria are followed worldwide [38]. However, in 2009, a new proposal was put forth by HLH society [39]. Diagnostic criteria as described by the existing and proposed are tabulated in Table 3.

\begin{tabular}{|c|c|}
\hline HLH 2004 diagnostic criteria & Proposed diagnostic criteria 2009 \\
\hline $\begin{array}{l}\text { a. Molecular diagnosis consistent with HLH. Pathologic mutations of PRF1, UNC13D or } \\
\text { STX11 are identified. }\end{array}$ & $\begin{array}{l}\text { a. Molecular diagnosis consistent with } \mathrm{HLH} \text { or X-linked lymphoproliferative } \\
\text { syndrome }(\mathrm{XLP}) \text {. }\end{array}$ \\
\hline OR & OR \\
\hline $\begin{array}{l}\text { b. Fulfilment of five of eight of the following criteria } \\
\text { - Fever } \\
\text { - } \\
\text { - } \\
\text { - }\end{array}$ & $\begin{array}{ll}\text { - } & \text { b. Fulfilment of at least three of four following criteria } \\
\text { - } & \text { Fever } \\
\text { - Splenomegaly } \\
\text { - } & \text { Cytopenias (minimum } 2 \text { cell lines reduced) } \\
\text { - Hepatitis }\end{array}$ \\
\hline
\end{tabular}




\begin{tabular}{|c|c|}
\hline 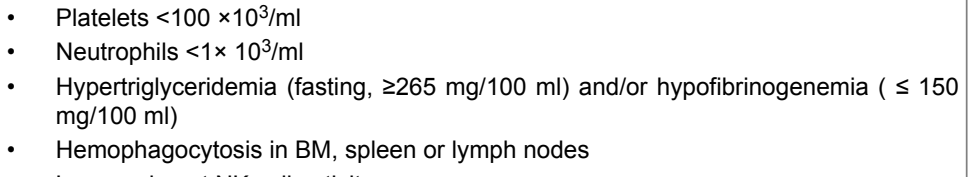 & $\begin{array}{ll}\text { - } & \text { c. Fulfilment of at least one of four following criteria } \\
\text { - } & \text { Hemophagocytosis } \\
\text { - } & \uparrow \text { Ferritin } \\
\text { - } & \uparrow \text { slL2Ra (age based) } \\
\text { - } & \text { Absent or very decreased NK function }\end{array}$ \\
\hline $\begin{array}{ll}\text { - } & \text { Ferritin } \geq 500 \mathrm{ng} / \mathrm{ml} \\
\text { - } & \text { Soluble } \mathrm{CD} 25 \text { (soluble } \mathrm{IL}-2 \text { receptor) }>2400 \mathrm{U} / \mathrm{ml} \text { (or per local reference laboratory) }\end{array}$ & $\begin{array}{l}\text { d. Other supportive diagnostic features } \\
\text { - } \quad \text { Hypertriglyceridemia } \\
\text { - } \quad \text { Hypofibrinogenemia } \\
\text { - } \quad \text { Hyponatremia }\end{array}$ \\
\hline
\end{tabular}

Table 3: HLH 2004 diagnostic criteria and HLH proposed diagnostic criteria 2009.

\section{Treatment}

Success rates have been found to be dependent on early/timely diagnosis and prompt initiation of treatment. Treatment should be directed at controlling the triggering infection, arresting the proliferation and further activation of T-cells. Inhibiting the production of cytokines that promote inflammatory process will prevent further activation of inflammatiory mediators which in turn will control or stop the further damage [40].

Treatment has been classified as supportive and specific therapy.

\section{Supportive therapy}

Supportive therapy aims at addressing the infection, source of infection, replacement of blood volume, and in severe cases cardiorespiratory support. Broad-spectrum antibiotics, as per culture report and clinical need are to be administered either orally or parenterally based on severity of the infection [41]. Prophylactic therapy with cotrimoxazole, oral antimycotic agents i.e., fluconazole and antiviral therapy are to be considered in patients with evidence of viral infection.
Administration of Intravenous (IV) immunoglobulin $(0.5 \mathrm{~g} / \mathrm{kg})$ once every 4 weeks is advised during the initial phase and as per need in continuation therapy. Rituximab is to be considered for those with Ebstein Bar virus infection triggered HLH. Few patients require blood volume replacement particularly those with HLH induced bleeding, clotting factor derangements. Transfusion of blood products, packed red blood cells, platelets, fresh frozen plasma, cryoprecipitate, and occasionally activated factor VII is followed. Cardio-respiratory support, dialysis for renal failure patients may be required in few critically ill children.

\section{Specific management}

Dexamethasone alone controls the disease significantly in many secondary HLH. However, additional medications may be required in severe HLH whether it is secondary/familial; in such cases, etoposide, Cyclosporine are administered in the treatment along with dexamethasone and intrathecal methotrexate therapy is considered in case of CNS involvement (Table 4).

\begin{tabular}{|c|c|c|}
\hline SI No & Drug & Dose and Duration \\
\hline \multicolumn{3}{|c|}{ Initial therapy } \\
\hline 1 & Etoposide & $150 \mathrm{mg} / \mathrm{m}^{2}$, Intravenous, twice a week for week 1-2; once a week for week 3-8* \\
\hline 2 & Dexamethasone & $\begin{array}{l}10 \mathrm{mg} / \mathrm{m}^{2} / \text { day for initial } 2 \text { weeks, } \\
5 \mathrm{mg} / \mathrm{m}^{2} / \text { day during wee } 3-4 \text {, } \\
5-2.5 \mathrm{mg} / \mathrm{m}^{2} / \text { day week } 4-6 \\
1.25 \mathrm{mg} / \mathrm{m}^{2} / \text { day week } 7-8 \text {. }\end{array}$ \\
\hline 3 & Cyclosporin $\mathrm{A}^{+}$ & $\begin{array}{l}\text { Initiate } 6 \mathrm{mg} / \mathrm{kg} \text { daily ( } 2 \text { divided doses) if kidney function is normal. Aim is to achieve } \\
\text { trough levels around } 200 \text { microgram/L. }\end{array}$ \\
\hline \multirow[t]{2}{*}{4} & Methotrexate-Intrathecal & $\begin{array}{l}6 \mathrm{mg} \text { for children aged } 1 \mathrm{yr} \\
8 \mathrm{mg} \text { for children aged } 1-2 \mathrm{yrs} \\
10 \mathrm{mg} \text { for children aged } 2-3 \mathrm{yrs} \text {, } \\
12 \mathrm{mg} \text { for children aged } 3 \mathrm{yrs}\end{array}$ \\
\hline & Prednisolone-Intrathecal & $\begin{array}{l}4 \mathrm{mg} \text { for children aged } 1 \mathrm{yr} \\
6 \mathrm{mg} \text { for children aged } 1-2 \mathrm{yrs} \text {, } \\
8 \mathrm{mg} \text { for children aged } 2-3 \mathrm{yrs} \text {, } \\
10 \mathrm{mg} \text { for children aged } 3 \mathrm{yrs} \text {. }\end{array}$ \\
\hline
\end{tabular}




\begin{tabular}{|l|l|l|}
\hline 1. & Etoposide & $150 \mathrm{mg} / \mathrm{m}^{2}$ intravenous, every second week. \\
\hline 2. & Dexamethasone & Pulses every $2^{\text {nd }}$ week, $10 \mathrm{mg} / \mathrm{m}^{2}$ for $3 \mathrm{days}$. \\
\hline 3. & Cyclosporin A & Dose is adjusted to achiever blood levels around $200 \mathrm{mcg} / \mathrm{L}$ \\
\hline${ }^{*}$ Not to consider if absolute neutrophil count (ANC) $0.5 \times 10^{9} / \mathrm{L}$ and the bone marrow is hypocellular. \\
${ }^{+}$Dose of Cyclosporine is determined by the blood levels.
\end{tabular}

Table 4: Initial 8-weeks therapy and maintenance therapy.

When methotrexate and Prednisolone are administered intrathecally, evaluation of CSF to be done at the time of diagnosis and after 2 weeks. If there is clinical evidence of progressive neurological symptoms or abnormal CSF (cells/protein), additional CNS-therapy is initiated with 4 weekly intrathecal injections.

CNS Involvement diagnosed by CSF spread or imaging findings can prove detrimental owing to long term deficits, neurological complications and requires aggressive treatment with weekly injections of intrathecal methotrexate and Hydrocortisone. In addition, HLH chemotherapy to be administered until no abnormality is detected in CSF and symptoms disappear. Dexamethasone helps in reduction of CNS involvement partly by penetrating the blood brain barrier.

Involvement of CNS is predominantly suggestive of a genetic etiology and risk of significant long term morbidity is high. It has been advised to consider Hematopoeitic Stem Cell Transplant for such patients.

\section{Continuation therapy}

Initial therapy is continued with an aim to keep the disease inactive (week 9-40). It is advisable to continue the therapy in Non-familial diseases/no genetic evidence of HLH, only if the disease is active after initial therapy.

In case of genetically proven HLH after initial therapy once disease is under control, HSCT is mandatory.

\section{Stem cell transplantation}

In primary HLH, which is genetically proven, allogeneic Stem Cell Transplant (SCT) is the only curative therapy. For stem cell transplantation, an HLA-identical donor is preferable. The risk of a sibling carrying the disease must be considered; carrier state is less likely if older sibling is considered as donor, but this age criteria cannot be used as an indicator for being non-affected. In the absence of a genetic marker (as perforin/hMunc), NK-cell activity can be considered as a surrogate marker of immune dysfunction. In situations of non-availability of an HLA-identical relative, SCT with a matched unrelated donor is recommended. If there is no matched donor available, a mismatched donor (including a haploidentical family donor) or cord blood is suggested, as decided by the physician. The therapeutic outcomes with mismatched donors are improving in the recent past. SCT to be considered in primary HLH once the disease is under control after the initial therapy [42].

\section{New approaches in therapy}

Despite all aggressive measures, it is difficult to halt the progress of $\mathrm{HLH}$ and not everyone can undergo SCT. Hence new approaches to salvage such patients are under trials. A combination of Etoposide with Anti Thymocyte Globulins looks like an interesting and promising option to improve the outcomes by increasing initial responses and maintaining them until HSCT can be performed in primary/refractory cases. Plasmapheresis to remove excessive cytokines has been performed in few with temporary benefit. Various monoclonal antibodies such as alemtuzumab, infliximab, and daclizumab [43,44] has been described in various case reports with appreciable success rate. Alemtuzumab targets the CD-52 antigen, which is expressed on most lymphocytes, monocytes, macrophages, and dendritic cells. Infliximab and daclizumab targets TNF, CD52 respectively. Rituximab has been used in EBV triggered HLH though with varied success rate. Splenectomy and liver transplant for refractory cases has been proposed with limited success. Being a rare disorder and with lack of data, there is still a long way to develop treatment strategies for refractory and resistant HLH disease. More evidence is required before these can be offered as definitive cure.

\section{Conclusion}

HLH is a potentially fatal condition is often under diagnosed, missed in children and adults. High index of suspicion in patients presenting with fever, hepatosplenomegaly, pancytopenia, liver dysfunction and coagulopathy is required for diagnosis. Though biochemical markers and tissue diagnostic markers fulfil diagnostic criteria genetic analysis is warranted in all relevant cases as it has specific therapeutic and prognostic implication. Secondary HLH carries good prognosis and at times responds to steroid treatment alone whereas primary/familial HLH can be fatal without SCT after initial phase of therapy. There is a definite paucity of data from India related to HLH and we need studies concentrating on genetic analysis and modified treatment modalities practical to developing countries.

\section{Acknowledgement}

We acknowledge the writing assistance provided by Dr. Latha MS, Research Consultant, Rainbow children's hospital, Banjara Hills, Hyderabad, India.

\section{References}

1. Farquhar JW, Claireaux AE (1952) Familial haemophagocytic reticulosis. Arch Dis Child 27: 519-525.

2. Henter JI, Elinder G, Söder O, Ost A (1991) Incidence in Sweden and clinical features of familial hemophagocytic lymphohistiocytosis. Acta Paediatr Scand 80: 428.

3. Ramos-Casals M, Brito-Zerón P, López-Guillermo A, Khamashta MA, Bosch X4 (2014) Adult haemophagocytic syndrome. Lancet 383: 1503-1516. 
4. Jordan MB, Allen CE, Weitzman S, Filipovich AH, McClain KL (2011) How I treat hemophagocytic lymphohistiocytosis. Blood 118: 4041-4052.

5. Clementi R, Emmi L, Maccario R, Liotta F, Moretta L, et al. (2002) Adult onset and atypical presentation of hemophagocytic lymphohistiocytosis in siblings carrying PRF1 mutations. Blood 100: 2266-2267.

6. Göransdotter Ericson K, Fadeel B, Nilsson-Ardnor S, Söderhäll C, Samuelsson A, et al. (2001) Spectrum of perforin gene mutations in familial hemophagocytic lymphohistiocytosis. Am J Hum Genet 68: 590-597.

7. Feldmann J, Callebaut I, Raposo G, Certain S, Bacq D, et al. (2003) Munc13-4 is essential for cytolytic granules fusion and is mutated in a form of familial hemophagocytic lymphohistiocytosis (FHL3). Cell 115: 461-473.

8. zur Stadt U, Schmidt S, Kasper B, Beutel K, Diler AS, et al. (2005) Linkage of familial hemophagocytic lymphohistiocytosis (FHL) type-4 to chromosome $6 \mathrm{q} 24$ and identification of mutations in syntaxin 11. Hum Mol Genet 14: 827-834.

9. Freeman HR, Ramanan AV (2011) Review of haemophagocytic lymphohistiocytosis. Arch Dis Child 96: 688-693.

10. Ménasché G, Pastural E, Feldmann J, Certain S, Ersoy F, et al. (2000) Mutations in RAB27A cause Griscelli syndrome associated with haemophagocytic syndrome. Nat Genet 25: 173-176.

11. Rubin CM, Burke BA, McKenna RW, McClain KL, White JG, et al. (1985) The accelerated phase of Chediak-Higashi syndrome. An expression of the virus-associated hemophagocytic syndrome? Cancer 56: 524-530.

12. Emile JF, Abla O, Fraitag S, Horne A, Haroche J, et al. (2016) Revised classification of histiocytoses and neoplasms of the macrophage-dendritic cell lineages. Blood 127: 2672-2681.

13. Janka GE, Schneider EM (2004) Modern management of children with haemophagocytic lymphohistiocytosis. Br J Haematol 124: 4-14.

14. Pachlopnik Schmid J, Côte M, Ménager MM, Burgess A, Nehme N, et al. (2010) Inherited defects in lymphocyte cytotoxic activity. Immunol Rev 235: 10-23.

15. Risma K, Jordan MB (2012) Hemophagocytic lymphohistiocytosis: updates and evolving concepts. Curr Opin Pediatr 24: 9.

16. Egeler RM, Shapiro R, Loechelt B, Filipovich A (1996) Characteristic immune abnormalities in hemophagocytic lymphohistiocytosis. J Pediatr Hematol Oncol 18: 340-345.

17. Eife R, Janka GE, Belohradsky BH, Holtmann H (1989) Natural killer cell function and interferon production in familial hemophagocytic lymphohistiocytosis. Pediatr Hematol Oncol 6: 265.

18. Ishii E, Ueda I, Shirakawa R, Yamamoto K, Horiuchi H, et al. (2005) Genetic subtypes of familial hemophagocytic lymphohistiocytosis: correlations with clinical features and cytotoxic $\mathrm{T}$ lymphocyte/natural killer cell functions. Blood 105: 3442.

19. Stepp SE, Dufourcq-Lagelouse R, Le Deist F, Bhawan S, Certain S, et al. (1999) Perforin gene defects in familial hemophagocytic lymphohistiocytosis. Science 286: 1957.

20. Takeuchi O, Akira S (2010) Pattern recognition receptors and inflammation. Cell 140: 805-820.

21. Aricò M, Danesino C, Pende D, Moretta L (2001) Pathogenesis of haemophagocytic lymphohistiocytosis. Br J Haematol 114: 761.

22. Komp DM, McNamara J, Buckley P (1989) Elevated soluble interleukin-2 receptor in childhood hemophagocytic histiocytic syndromes. Blood 73: 2128.

23. Tang Y, Xu X, Song H, Yang S, Shi S, et al. (2008) Early diagnostic and prognostic significance of a specific Th1/Th2 cytokine pattern in children with haemophagocytic syndrome. Br J Haematol 143: 84-91.

24. Fall N, Barnes M, Thornton S, Luyrink L, Olson J, et al. (2007) Gene expression profiling of peripheral blood from patients with untreated new-onset systemic juvenile idiopathic arthritis reveals molecular heterogeneity that may predict macrophage activation syndrome. Arthritis Rheum 56: 3793
25. Behrens EM, Canna SW, Slade K, Rao S, Kreiger PA, et al. (2011) Repeated TLR9 stimulation results in macrophage activation syndromelike disease in mice. J Clin Invest 121: 2264-2277.

26. Risdall RJ, Brunning RD, Hernandez JI, Gordon DH (1984) Bacteriaassociated hemophagocytic syndrome. Cancer 54: 2968-2972.

27. Sung PS, Kim IH, Lee JH, Park JW (2011) Hemophagocytic Lymphohistiocytosis (HLH) Associated with Plasmodium vivax Infection: Case Report and Review of the Literature. Chonnam Med J 47: 173-176.

28. Miyahara M, Sano M, Shibata K, Matsuzaki M, Ibaraki K, et al. (2000) Bcell lymphoma-associated hemophagocytic syndrome: clinicopathological characteristics. Ann Hematol 79: 378.

29. Usmani GN, Woda BA, Newburger PE (2013) Advances in understanding the pathogenesis of HLH. Br J Haematol 161: 609-622.

30. Rosado FG, Kim AS (2013) Hemophagocytic lymphohistiocytosis: an update on diagnosis and pathogenesis. Am J Clin Pathol 139: 713-727.

31. Lee WI, Chen SH, Hung IJ, Yang CP, Jaing TH, et al. (2009) Clinical aspects, immunologic assessment, and genetic analysis in Taiwanese children with hemophagocytic lymphohistiocytosis. Pediatr Infect Dis J 28: 30 .

32. Maciejewski J, Selleri C, Anderson S, Young NS (1995) Fas antigen expression on CD34+ human marrow cells is induced by interferon gamma and tumor necrosis factor alpha and potentiates cytokinemediated hematopoietic suppression in vitro. Blood 85: 3183-90

33. Balwierz W, Czogala M, Pawinska-Wasikowska K, Cwiklinska M, Walicka-Soja K (2010) Hemophagocytic lymphohistiocytosis: diagnostic problems in pediatrics. Przegl Lek 67: 417-24.

34. Ibarra MF, Klein-Gitelman M, Morgan E, Proytcheva M, Sullivan C, et al. (2011) Serum Neopterin Levels as a Diagnostic Marker of Hemophagocytic Lymphohistiocytosis Syndrome. Clin Vaccine Immunol 18: 609-614.

35. Weitzman S (2011) Approach to hemophagocytic syndromes. Hematology Am Soc Hematol Educ Program 2011: 178-183.

36. Chandrakasan S, Filipovich AH (2013) Hemophagocytic lymphohistiocytosis: advances in pathophysiology, diagnosis, and treatment. J Pediatr 163: 1253-1259.

37. Schneider EM, Lorenz I, Muller-Rosenberger M, Steinbach G, Kron M, et al. (2002) Hemophagocytic lymphohistiocytosis is associated with deficiencies of cellular cytolysis but normal expression of transcripts relevant to killer-cell-induced apoptosis. Blood 100: 2891-2898.

38. Henter JI, Horne A, Arico M, Egeler RM, Filipovich AH, et al. (2007) HLH-2004: diagnostic and therapeutic guidelines for hemophagocytic lymphohistiocytosis. Pediatr Blood Cancer 48: 124-131.

39. Filipovich AH (2009) Hemophagocytic lymphohistiocytosis (HLH) and related disorders. Hematology Am Soc Hematol Educ Program.

40. Bode SF, Lehmberg K, Maul-Pavicic A, Vraetz T, Janka G, et al. (2012) Recent advances in the diagnosis and treatment of hemophagocytic lymphohistiocytosis. Arthritis Res Ther 14: 213.

41. Kodan P, Chakrapani M, Shetty M, Pavan R, Bhat P (2015) Hemophagocytic lymphohistiocytosis secondary to infections: A tropical experience. J Postgrad Med 61: 112-115.

42. Ouachée-Chardin M, Elie C, de Saint Basile G, Le Deist F, Mahlaoui N, et al. (2006) Hematopoietic stem cell transplantation in hemophagocytic lymphohistiocytosis: a single-center report of 48 patients. Pediatrics 117: e743-750.

43. Machaczka M, Vaktnäs J, Chiang SC, Bryceson YT (2010) Alemtuzumab treatment for hemophagocytic lymphohistiocytosis. Nat Rev Clin Oncol 7.

44. Marsh RA, Allen CE, McClain KL, Weinstein JL, Kanter J, et al. (2013) Salvage therapy of refractory hemophagocytic lymphohistiocytosis with alemtuzumab. Pediatr Blood Cancer 60: 101-109. 